\title{
Construction and Application of Online Open Courses in Independent Colleges Against the Background of "Internet Plus Education"
}

\author{
Songchun Wang \\ Beijing Institute of Technology, Zhuhai \\ Zhuhai, China 519088
}

\author{
Ting Qin* \\ Zhuhai Technician College \\ Zhuhai, China 519000 \\ *Corresponding Author
}

\begin{abstract}
The advent of the Internet era has brought us tremendous changes in people's life and learning, subverted the deep-rooted teaching mode of traditional education in China, and become the future development direction of education in China. Independent Colleges as higher institutions of Education in China, the implementation of Internet Plus Education has promoted the construction and development of online open courses in independent colleges. Based on this, this paper expounds the impact of Internet Plus Education on independent colleges, and analyzes the significance and problems of online open curriculum construction in Independent Colleges under Internet Plus Education, and further explores the application strategies of online open courses in Independent Colleges under Internet Plus Education.
\end{abstract}

Keywords-Internet Plus Education; independent colleges; online open courses

\section{INTRODUCTION}

With the continuous development of Internet + Education and the rise and development of internet online open courses in recent years, the Ministry of Education of China issued the "Opinions on Strengthening the Application and Management of Online Open Courses in Colleges and Universities" (hereinafter referred to as Opinions), in 2015, which has opened up the construction and further development of online courses in colleges and universities. Among them, the "opinion" clearly points out that "all colleges and universities should apply online open courses through online schools, online learning and curriculum teaching in combination with their own talent training objectives and needs, and constantly innovate in teaching, realize the sharing of courses within and between schools, and improve the effectiveness of teaching." It can be said that the proposal of "Opinions" provides a new development direction for Internet Education in Independent Colleges.

\section{The INFLUENCE OF INTERNET Plus EdUCATION ON INDEPENDENT COLLEGES}

\section{A. Influence of Network on Classroom Teaching}

First of all, from the perspective of teaching concept, most of the college students in the school are born in the 1995s and 2000s. In this period, the students have ideas and personalities, and are influenced by the Internet since childhood. Therefore, in the teaching of independent colleges, the traditional teacher led teaching concept has been difficult to meet the students' learning needs. Especially with the popularity of smart phones, more and more students are unable to concentrate on listening in class. The network and smart phones have become the necessities of students life. As an independent college teaching management department, how to carry out teaching reform based on students' interests has become a major issue; Secondly, from the perspective of teaching mode, multimedia, micro class, electronic whiteboard and other information technology teaching have been gradually implemented in teaching, overturning the constraints of traditional classroom time and space, making the classroom more open, which has become the future development trend of teaching in independent colleges. Finally, from the perspective of teaching subject, students change from traditional passive acceptance of knowledge to active exploration of knowledge. Through the network, not only the breakthrough in teaching space and time is realized, but also the enthusiasm and initiative of students' learning is improved to a certain extent, let teacherstudent interaction become a new way of teaching.

\section{B. Challenges to Teachers' Literacy Under Internet Education}

Under the Internet, the traditional teaching concept and teaching mode are completely subverted, which not only brings certain influence to students' learning, but also brings great challenges to teachers' teaching. First of all, the challenge to teachers' teaching concept is that traditional teachers are all teaching methods based on indoctrination, and they believe that a lesson plan can be taught for a lifetime. Under the mode of Internet + education, students 
have become the main body of the classroom. Teachers should develop teaching based on students' interests and self characteristics, so that students can learn actively. Secondly, it is the challenge to teachers' teaching level. Under the Internet + Education, the single teaching mode of teachers is no longer applicable. More teachers are required to constantly grope for and innovate in the teaching process, such as flipped classroom implementation, moody teaching, micro class teaching and other teaching modes can promote the further development of Internet + Education. Finally, it is a challenge to teachers' information technology. There is no doubt that the implementation of Internet + Education is inseparable from the support of information technology. Only with professional knowledge and computer knowledge can teachers integrate cultural teaching and information technology better, and promote further construction and development of online open courses in independent colleges under internet + education.

\section{THE SIGNIFICANCE OF ONLINE OPEN CURRICULUM CONSTRUCTION IN INDEPENDENT COLLEGES UNDER INTERNET PLUS EDUCATION}

\section{A. Breaking Through the Traditional Classroom Constraints and Improving Teaching Efficiency}

In the teaching of traditional independent colleges, classroom is the main carrier of teachers' teaching, and also the main way for students to acquire knowledge. With the development of internet in recent years, smart phones have gradually become an essential part of students' study and life. More and more students are attracted by mobile phones in the classroom. There are not a few students playing with mobile phones, sleeping and driving errands in the classroom. In addition, the individual differences between students and the lack of classroom caused by various reasons seriously affect the teaching efficiency. The construction of online open courses in independent colleges under Internet + Education has replaced traditional Blackboard + Chalk teaching forms by multimedia, network platform and mobile phone APP. It can not only explain knowledge in mobile phone, computer and other Internet terminals in classroom, but also achieve timely and effective communication between teachers and students in the platform. Besides, it can also enable students to break through. Unifies the classroom time and the spatial restraint, enables the student to carry on the selective, the targeted study according to own demand, has greatly enhanced the student's study interest and the classroom teaching efficiency.

\section{B. Promoting the Development of Internet Plus Education in Colleges and Universities}

With the proposal of China's 2015 opinion, independent colleges, as the backbone of higher education in China, carry out the construction of online open courses in independent colleges, which conforms to the latest education concept put forward by the Ministry of education of China, and opens a new chapter in the education of Independent Colleges and universities in China. For the education of colleges and universities in China, the construction and application of online open courses is not only the future development trend of independent colleges, but also the future development direction of the whole education field. Therefore, the construction of online open courses in independent colleges and universities has promoted the development of Internet + education in universities to a certain extent, and has laid a good foundation for the construction of internet education system.

\section{Improving Students' Learning Autonomy and Realizing Individualized Teaching}

Under the Internet + Education, the traditional teaching mode has been subverted, and students have been separated from the constraints of traditional classroom, so that students can have a broader learning space. First of all, the rich teaching resources and innovative teaching mode under the Internet + Education bring students endless fresh and interest, can effectively mobilize the enthusiasm and autonomy of students' learning. Secondly, Internet + Education has changed the traditional way of communication between teachers and students, It enables students to realize real-time interaction with teachers in or under class, breaks through the constraints of traditional classroom time and space, and is of great significance to strengthen the communication between teachers and students and improve the learning efficiency of students. Finally, under the Internet + Education, students can learn from their own needs under the teaching platform of the internet, and explore themselves according to their own interests, in this way, it can get rid of the shackles of one-size-fits-all in traditional teaching, achieve the autonomy of students' learning, promote students' personalized learning and development, and lay a good foundation for students' future study and work.

\section{PROBLEMS ENCOUNTERED IN THE CONSTRUCTION OF ONLINE OPEN COURSES IN INDEPENDENT COLLEGES UNDER INTERNET PLUS EDUCATION}

\section{A. Backward Teaching Concept}

In the teaching of traditional independent colleges, teachers are the main body of teaching, so in the traditional classroom, more attention is paid to "teaching", teachers are the main body of teaching, students are auxiliary, the importance of teaching is emphasized in the whole process, and what students do is to complete the exercises arranged by teachers under class. Students are in a passive position in the whole learning process. It is precisely because of the restriction of the educational concept of China that students gradually form a learning habit of "feeding a stutter and eating a bite" in the process of education. In the teaching of online open courses, students mainly study independently. On the one hand, students learn knowledge by watching teaching videos independently; on the other hand, students explore problems and report knowledge through group cooperation. In this way, the state of students' passive learning can't be changed in a short period of time, resulting in a big dilemma in the construction of online open courses, which is very harmful to students' learning and development 
independent colleges under Internet + Education, it is imperative to update teaching concepts.

First of all, as the imparters of knowledge, the teaching idea of teachers in colleges and universities is very key. It should not only "give them fish", but also "teach them how to fish" from the perspective of students' interests and future development. While teaching students knowledge and skills, students are guided to master learning methods, students are guided to learn independently, so as to realize online open course teaching effectiveness. Secondly, teachers should pay attention to the role transformation between teachers and students in teaching, let teachers from the traditional dominant position of teaching, create an open, equal and harmonious learning environment for students, so as to encourage students to actively participate in learning, and comprehensively improve students' interest in learning and learning efficiency; in addition, teachers should guide students to choose the knowledge they are interested in or don't master according to their own interests and characteristics in internet teaching, break through the shackles of traditional classroom teaching, and realize the personalized teaching of online open courses. Finally, teachers should strengthen the effective interaction between teachers and students in the teaching process, and guide students to use online open courses to teach the real-time interaction between students, give full play to the advantages of online open course teaching, and help independent colleges and universities to further improve their teaching level.

\section{B. Increasing Investment in Construction}

In order to establish online open courses in the teaching of independent colleges, the cooperation and support of universities and teaching management departments are inseparable. First of all, hope that the teaching management department of independent colleges can establish a strong sense of internet + education, clarify the impact of Internet + education on teaching management in independent colleges, and provide financial support for the construction of internet + education fundamentally, laying a good foundation for independent colleges to carry out line open curriculum construction. Secondly, the teaching management departments of independent colleges and universities should further construct the management methods related to online open curriculum construction and online open curriculum, gradually improve the online open curriculum construction system, in order to ensure the smooth development and implementation of online open curriculum construction in Independent Colleges. For example, in the course of setting up online open courses in independent colleges, in addition to identifying and specifying regulations on the workload of the instructors, it is also necessary to set up the relevant norms of the course construction, procedures, online teaching mode and online resource sharing in Colleges and universities, establish and improve the relevant measures for the construction and management of online courses, so as to provide the necessary institutional guarantee for the construction of on-line open course. Finally, it is necessary to continue to strengthen the construction of online courses has laid the dominant position of students in the classroom. Therefore, in order to fully implement online open courses in 
in Independent Colleges and universities, continue to strengthen the promotion and application of online open courses, find out the problems in time through the application, and constantly improve and reform, so as to comprehensively promote the construction and development of online open courses independent colleges, and comprehensively improve the teaching quality of independent colleges.

\section{Improving the Quality of Teachers}

As the constructors of classroom and the imparters of knowledge, teachers' professional skills, modern teaching technology and teaching mode directly affect the construction and implementation of online open curriculum. Therefore, as teachers of independent colleges, first of all, they should have professional knowledge and skills, and be able to carry out professional skills teaching based on the students' teaching materials and the needs of modern personnel training. They should not only teach students basic professional theoretical knowledge, but also strengthen students' practice in teaching, so as to lay a good foundation for students to move towards the society in the future, adapt to the social needs faster and better. Secondly, teachers should constantly improve their own modern professional technology. On the one hand, as independent colleges, it is necessary to recruit some teachers with modern teaching level to hold a post, so as to drive the continuous improvement of the information technology of in-service teachers in independent colleges. On the other hand, it is necessary to strengthen the training and secondary learning of the computer operation ability of the teachers in service, so that they can be proficient in the use of computers, master the production and practice ability of computer courseware flexibly, and ensure that online open courses can be set up and implemented. At the same time, It is indispensable to establish the connection between the professional teachers in service and the professional teachers in other colleges and universities, learn the advantages of other colleges and universities in online open curriculum construction and courseware making, so as to constantly improve themselves and perfectly themselves. Moreover, teachers should rely on the Internet online open courses to innovate the teaching mode and optimize the teaching process. On the one hand, the use of information-based teaching equipment to fully stimulate students' enthusiasm and enthusiasm for learning, guide students to imagine and create; On the other hand, It is necessary to full use of online open courses to strengthen the effective interaction between teachers and students, help students in-depth learning and thinking, and lay a good foundation for students' future learning and development. Finally, it is also necessary to constantly improve the comprehensive skills of teachers. In the process of online open course construction, teachers are required not only to have professional knowledge and skilled computer operation skills, but also to have modern management ability. Therefore, in the whole process of the construction of online open courses, teachers are also a learner, but also the beneficiaries of online courses. Therefore, as guidance teachers, it is indispensable to strengthen training and learning from the aspects of concept, management, technology, teaching and so on, and to improve their own literacy in an all-round way, and better contribute to the construction of online open courses.

\section{CONCLUSION}

In summary, with the advent of the Internet Plus Education era, online open courses have become the development trend and direction of independent education in the future. It is of great significance to improve teaching efficiency and cultivate students' autonomous learning ability. Therefore, as independent colleges, it is necessary to clarify the impact and challenges brought about by the Internet Plus Education, change concepts, update technology, and improve teacher quality, create more efficient online classrooms for students, and comprehensively improve the effectiveness of independent college teaching.

\section{REFERENCES}

[1] Li Xuezheng. Thinking and practice of online open course construction in Applied Undergraduate Universities Based on the background of "Internet + education" [J]. Journal of multimedia and network teaching in China (last ten days)2019(06):38-39. (in Chinese)

[2] Xu Xiaohui, Guo Xinyi. The construction and optimization of online courses in colleges and universities based on Internet [J]. Modernization of Education, 2018, 5 (24): 100-102. (in Chinese)

[3] Feng Xiaoyan . A probe into the Reform of classroom Teaching Mode in Colleges and Universities under the background of "Internet Education" [J]. Journal of Chuzhou University, 2017,19 (02): 106107+136. (in Chinese) 